\title{
Towards Improving Performance of the Construction Industry in Ghana: A SWOT Approach
}

\author{
Frimpong, B.E. ${ }^{1}$, Sunindijo, R.Y. ${ }^{*}$, and Wang, C. ${ }^{1}$
}

\begin{abstract}
The construction industry is the second largest contributor to Gross Domestic Product (GDP) and a significant driver of economic activities in Ghana. Given the importance of the construction industry in boosting the national economy, it is essential to develop effective strategies to keep improving the performance of the industry. To achieve this aim, this research conducted the strengths, weaknesses, opportunities and threats (SWOT) analysis of the Ghanaian construction industry. Underpinned by the SWOT analysis, strategic recommendations are provided to minimise the weaknesses and to neutralise the threats that confront the industry, while taking advantage of the strengths and exploiting the opportunities presented to it. These include investment to facilitate innovation and growth, human resource development, development and enforcement of policy and standards, and conducive procurement practice. The recommendations are expected to provide practical and theoretical directions to the industry's stakeholders on effective ways to improve the industry's performance.
\end{abstract}

Keywords: Construction industry; Ghana; SWOT; performance.

\section{Introduction}

Construction has a strong linkage with many economic activities and whatever happens to the construction industry will directly and/or indirectly influence other sectors of the economy and ultimately, the wealth of a country [1]. Likewise, the construction industry is a significant driver of economic activities in Ghana and contributes to both industrial output and overall Gross Domestic Product (GDP). The construction industry is critical to Ghana's economic health because of its size and its role as a driver of growth. The industry contributed $5.7 \%$ to the GDP in 2006 [2], but this has improved significantly over the years. The sector recorded GDP contributions of $13.5 \%$ in $2015,13.7 \%$ in 2016 , and $13.7 \%$ in 2017 [2]; showing a $240 \%$ quantum leap within a decade. In terms of economic activities, the construction sector became the second most significant contributor of GDP to the Ghanaian economy in 2017.

The construction industry in Ghana also provides for a large number of employment opportunities. It employed 316,368 and 309,132 working class people in the formal and informal sectors of the Ghanaian economy respectively. This represents $3.4 \%$ and $3.5 \%$ in the formal and informal sectors respectively; meaning nearly $7 \%$ of the working population in Ghana are engaged in construction [3].

${ }^{1}$ Faculty of Built Environment, UNSW Sydney, NSW 2052, AUSTRALIA.

* Corresponding author; email: r.sunindijo@unsw.edu.au

Note: Discussion is expected before July, $1^{\text {st }} 2020$, and will be published in the "Civil Engineering Dimension", volume 22, number 2, September 2020.

Received 17 December 2019; revised 11 May 2020; accepted 12 May 2020.
Considering the significance of the construction industry on the national economy, it is incumbent on all stakeholders, particularly the government, to work together to ensure the sector's health and growth. This includes developing effective strategies and responses to address the weaknesses and threats confronting the industry. The long-term success of the construction industry depends on how the internal strengths and weaknesses are matched with the external opportunities and threats [4]. The aim of this research is to use SWOT analysis as a systematic evaluation framework to gain insight into the Ghanaian construction industry. Ultimately, the findings from the analysis are used to recommend strategies to improve the performance of the industry and to promote economic and industrial development.

\section{SWOT Analysis}

SWOT analysis is a useful technique used to help organisations to identify strengths, weaknesses, opportunities, and threats related to business competition. SWOT analysis has been used by countless practitioners and researchers, and it is one of the most dominant tools of strategic planning. Glaister and Falshaw [5] found SWOT analysis as one of the highest ranked set of tools and analysis techniques used in strategic planning in companies in the United Kingdom (UK). Similarly, Panagiotou [6] argued that SWOT analysis is used more than any other strategic planning tool. Accordingly, Valentin [7] has advocated for SWOT analysis as the traditional means for searching for insights into ways of creating and maintaining a profitable fit between a commercial venture and its environment. Helms and Nixon [8], studied 141 peerreviewed academic research articles which used SWOT analysis. They found that the use of SWOT 
analysis has extended beyond companies to countries and industries and it is used in virtually every published business case.

In this research, the SWOT analysis is used to determine factors that influence the performance of the construction industry and to identify critical areas that need to be improved for the industry to operate effectively. Previously, researchers have used the SWOT analysis in the context of the construction industry. For instance, at the organisational level, Zhao and Shen [9] and Lu et al. [10] used SWOT analysis to assess the competitiveness of foreign construction firms in China and Chinese international construction companies respectively. At the industry level, Durdyev et al. [4] performed SWOT analysis for the construction industry in Cambodia.

\section{Strengths}

\section{Abundant Indigenous Materials}

The Ghanaian construction industry has plentiful supply of raw/indigenous materials and natural resources for construction. Cunningham and Cunningham [11] defined indigenous building material as any material that is locally produced and manufactured, naturally occurring, and abundant in a country. These include sand, coarse aggregates, cement, wood/timber, iron/ steel rods, roofing sheets, bamboo, clay, thatches, etc. Mogbo [12] remarked that materials constitute the largest input in construction, usually accounting for about half of the total cost of construction project; therefore, its abundant availability makes it a key contributor to the success of the industry.

\section{Large Pool of Cheap Labour}

In addition, the construction industry in Ghana has a large pool of human resources; skilled and unskilled. The level of managerial expertise and technical skills in architecture, construction, and engineering are relatively high in the Sub-Saharan region. There are several institutions in the country that train engineers, building technologist, project managers, etc for the industry. Moreover, the country has a huge number of unemployed and untrained youth with potential for training to receive the needed construction skills [13], ready to be employed in the event of an upsurge in construction activities. Again, like many other developing countries, labour in Ghana is comparatively cheap.

\section{Research and Development}

There is a publicly funded construction research organisation in Ghana. Established in 1952, the Building and Road Research Institute (BRRI), is mandated to conduct research, train and transfer technology in the construction and transportation sectors in Ghana. Over the years, the institute has performed a range of construction-related research, such as fast track construction methods, appropriate construction technologies, cost saving building technologies and development of alternative local building materials.

\section{Weaknesses}

The construction industry in Ghana has many weaknesses related to its structure, production process, physical characteristics, and composition that place the industry at a disadvantage relative to others.

Table 1 below summarises the problems and challenges of the construction industry relevant to developing countries and the Ghanaian construction industry.

In reference to the above, the weaknesses of the construction industry in Ghana may be summarised into the following categories; cost and time overruns, poor safety performance, poor workmanship, low technology, lack of effective barriers to entry, no single agency to oversee the industry, and poor materials quality.

\section{Opportunities}

\section{Urbanisation and Housing}

Rapid increase in population in Ghana has resulted in a large housing deficit, especially in urban areas. It is projected that the country needs at least 100,000 housing units annually while supply is estimated at $35 \%$ of the total need [21]. Other studies, for instance, Ghana Investment Promotion Centre [22] put the country's overall annual housing deficits between 110,000 and 140,000 units; and Institute of Statistical, Social and Economic Research (ISSER) [23] asserted a deficit of 70,000 and 120,000 housing units with only $30-35 \%$ of the annual estimated requirement being supplied. Even though there may be differences as to the exact estimate of the annual requirement, there is a consensus of a shortfall in the supply of housing, particularly in the urban areas. If this housing deficit is translated into effective demand for new dwellings, then this would create between 150,000 and 200,000 new jobs in construction [13]. This means that the challenges caused by population growth and urbanisation poses unique and vital opportunities for the construction industry to provide adequate housing and infrastructure.

\section{Infrastructure}

If the quality and quantity of urban housing is to be effectively addressed, it also means that new infrastructure is needed. Ghana's economic growth has put increasing strain on its transport and utilities infrastructure and created more resources to invest in 
Table 1. Weaknesses and Challenges Facing the Construction Industry in Developing Countries

\begin{tabular}{|c|c|}
\hline Authors & Summary of findings \\
\hline Laryea [14] & $\begin{array}{l}\text { Found that the challenges and weaknesses faced by contractors in Ghana are: } \\
\text { - } \text { difficult access to finance } \\
\text { - } \quad \text { payment delays and cumbersome payment processes } \\
\text { - } \text { poor design quality } \\
\text { - } \text { bribery and corruption } \\
\text { - } \text { poor contractor classification and low workloads } \\
\text { - lack of capacity to compete with foreign owned firms } \\
\text { - fragmentation of contractor representation bodies } \\
\text { - low technology } \\
\text { - } \quad \text { revadequate supervision of contracts and poor preparation for projects } \\
\text { - } \quad \text { politicisation of the contract bidding process and } \\
\text { - lack of effective barriers to entry. }\end{array}$ \\
\hline Ankomah et al. [15]; & Noted that in Ghana: \\
\hline Kheni [16] & $\begin{array}{l}\text { - there is a lack of commitment towards health and safety } \\
\text { - Construction workers work in unsafe environment }\end{array}$ \\
\hline Kpamma and Adjei- & Found that in Ghana construction projects record average \\
\hline Kumi [17] & $\begin{array}{l}\text { - } \quad \text { cost overrun of } 60 \% \text { to } 180 \% \\
\text { - } \quad \text { time overrun of between } 12 \text { to } 24 \text { months }\end{array}$ \\
\hline Ofori [18] & $\begin{array}{l}\text { Explored the problems which affected Ghanaian construction firms: } \\
\text { - inability to secure adequate working capital } \\
\text { - inadequate management } \\
\text { - insufficient engineering capacity } \\
\text { - poor workmanship }\end{array}$ \\
\hline Ofori-Kuragu et al. [19] & $\begin{array}{l}\text { Ranked the problems that affect the performance of Ghanaian contractors: } \\
\text { - } \quad \text { poor access to credit } \\
\text { - delays in payment from government and government agencies, } \\
\text { - cumbersome payment processes, } \\
\text { - bribery and corruption in the construction industry, } \\
\text { - contracts awarded based on one's political affiliation and } \\
\text { - the processes involved in becoming a construction firm are too easy. }\end{array}$ \\
\hline Williams [20] & $\begin{array}{l}\text { Studied over } 14,000 \text { local government projects in Ghana and revealed that one-third are never } \\
\text { completed. These include small but vital projects such as schools, health posts, etc. }\end{array}$ \\
\hline
\end{tabular}

improving it. The energy, manufacturing and transport sectors are driving demand for infrastructure expansion and improvement, as are population growth and urbanisation. Furthermore, many of the existing infrastructure are in poor state due to inadequate maintenance [24]. The need for adequate infrastructure to match economic and population growth in Ghana presents opportunities for the construction industry to develop business opportunities through the potential solutions.

\section{Discovery of Oil}

It has been established that there is a strong linkage between construction and economic activities. Therefore, the projected economic growth in Ghana and the emerging oil industry suggest that demand for construction goods and services will increase in the coming years. The discovery of crude oil in 2007 and the subsequent production of same from 2010 in the oilfields has fuelled several large-scale construction projects and new investments in real estate especially in the western region. Also, revenues from oil have mostly been allocated to capital expenditures in the national budget, including construction of infrastructure projects throughout Ghana [25]. Therefore, the construction industry can be optimistic of a positive impact on construction activities from oil and gas production [14].

\section{Attracting Foreign Firms}

Like many other developing countries, Ghana attracts many multinational firms to invest in its emerging market [26]. There are incentive packages designed to attract foreign investment and foreign firms including tax reliefs. For example, the Free Zones Act 1995 was passed to among other things, offer incentives such as tax concessions to companies granted licences under the Act. This has allowed many foreign contractors to engage in the construction industry through joint venture relationships. Moreover, many local contractors have worked with these foreign contractors as subcontractors and this facilitates all forms of technology transfer. The government's open-door policy in allowing foreign companies to compete freely for projects 
lead to improvement in local contractors' performance [27].

\section{Threats}

\section{Economic Factors}

The Ghanaian construction industry operates in an economy that has an unstable business environment and is characterised by high inflation, exchange and interest rates as well as high energy costs which negatively affect Ghanaian contractors' capital and profitability [28].

Inflation is one of the persistent threats confronting the economy of Ghana and is considered as a direct result of the policies of governments. Historically, the inflation rate in Ghana averaged 16.64\% from 1998 until 2018, reaching an all-time high of 63\% in March 2001 and a record low of $0.40 \%$ in May 1999. For instance, between the periods of December 2016 and December 2017, the official year-on-year inflation rate in Ghana ranged between $15.4 \%$ and $11.8 \%$ [29]. Inflation has a significant effect on the prices of construction materials [30]. An increase in the cost of materials affects the total cost of construction. Authors such as Kaming et al. [31] and Danso and Antwi [32] found that inflationary increases in building materials cost is a major cause of construction cost overruns.

Another threat is the fluctuated interest rates that have a serious impact on construction businesses. Many construction firms are reliant on bank loans to be able to get the project starting. An increase in the interest rate translates to a decrease in profits, thus firms may need to use more of their own resources to pay the increased interest on the loans. Interest rate in Ghana averaged 18.08\% from 2002 until 2018, with current benchmark interest rate at $17 \%$ [33]. With this high interest rate and huge collateral demands from banks, it become extremely difficult for construction firms to access loans [34].

Additionally, fluctuations in the exchange rates of currencies pose a threat to the construction industry in Ghana. Eiteman et al. [35] asserted that fluctuations in foreign exchange rates affect a firm's financial structure, reduce profit margins, and disrupt ongoing and future projects. The performance of the Ghanaian currency (Cedi, $\phi$ ) has been poor against the major trading currencies. For instance, the Cedi depreciated more than 104\% against the US dollar in only four years (From $\notin 2.16$ in 2013 to $\& 4.41$ in 2017 as shown in Table 2). In the construction industry, where profit margins can be tight due to competitive tendering, as well as reliance on the importation of some construction materials, equipment and services, currency fluctuations can have a significant fiscal impact on projects.
Table 2. Year-on-year z (Ghana Cedi vs US Dollar)

\begin{tabular}{lccccc}
\hline \multicolumn{1}{c}{ Years } & 2013 & 2014 & 2015 & 2016 & 2017 \\
\hline $\begin{array}{l}\text { Exchange rate } \\
\text { (vs US Dollar) }\end{array}$ & 2.16 & 3.20 & 3.80 & 4.20 & 4.41 \\
$\begin{array}{l}\text { Percentage } \\
\text { Depreciation (\%) }\end{array}$ & & 48.1 & 18.8 & 10.5 & 5.0 \\
\hline
\end{tabular}

Source: Bank of Ghana [33]

Furthermore, the rapid increases in fuel prices coupled with high energy cost also pose serious threat to the industry. For instance, between January 2008 and December 2018, the price of gasoline in Ghana increased from Ghф1.03/litre to Ghф4.98/litre, over $380 \%$ increase [36]. These rising costs in fuel and energy prices ultimately influences the cost of transportation as well as the operational cost of construction equipment.

\section{Financial Factors (Unpaid work/delayed pay- ment)}

The incidence of delayed payment or non-payment of works done by construction firms is a major threat to the performance of the construction industry in Ghana. Ofori et al. [34] asserted that effective and efficient financing of public sector projects in Ghana has been a challenge of the industry over a period with successive governments. One significant reason for construction project delays and sometimes leading to eventual abandonment of projects has been due to untimely honouring of certificate by client. Agyakwa-Baah [37] and Adams [38] provided evidence within the Ghanaian context by revealing that government's failure to promptly pay contractors for works done causes delays in construction of public. Unfortunately, this practice is persistent and even resulted in instances where some contractors on public projects embarked on street demonstrations to demand payments for projects long completed and utilised by the client. [39].

\section{Government and Politics}

Government policies normally translate into programmes and projects [40] and the construction industry is one of the key industries in which these projects are implemented. In Ghana, as in many developing countries, one major criterion for assessing the performance of the ruling party in government is through infrastructure projects. Accordingly, this demand places intense pressure on government to satisfy the people politically [37]. However, this political motivation could mean that infrastructure projects are not well planned and constructed according to real needs [41]. These unplanned infrastructure developments may lack the necessary funding and other required resources and coordination. This accounts for some of the reasons why many government projects are halted midconstruction or abandoned due to funding, price fluctuation or projects not needed again. 
Furthermore, the threat resulting from a change in political party in government has been identified [4244]. According to Williams [44], political regime change in Ghana is widely recognised as a cause of project delay or non-completion and a general change in policy direction within the construction industry. When there is change of government in Ghana, the new government comes with their own policies and plans for development, mostly fashioned out of their campaign manifestos. They tend to suspend or become nonchalant in many on-going projects which were initiated by the previous government in order not to give political points to opposition parties [43]. According to Ofori-Kuragu et al. [19], contractors perceive these acts of abandoning ongoing construction projects by successive governments as deliberate, because it gives the new government the opportunity to later re-award these same projects to their party members.

This supports the general perception within the industry that political affiliation is a major consideration in the award of contracts for public infrastructure projects [19]. Construction firms that are connected to the winning party and/or contributed to their electioneering campaign experience an increase in contracts because the institutional heads who award the contracts may be their party members. This shows a strong influence of the political system in Ghana on the construction procurement process.

\section{Unethical Procurement Practices}

There are widespread perceptions that public sector procurement is influenced by unethical payments which impact on the award of contracts for public projects. It is also perceived that sometimes even nonconstruction firms can be awarded construction contracts, then these projects are later sold to construction firm(s) to execute them [45]. Ameyaw et al. [46] used a structured questionnaire survey to elicit direct knowledge and life experiences of construction practitioners on corrupt practices in the Ghanaian construction industry. Their study uncovered habitual corrupt practices and unethical behaviour prevailing among public officials, construction firms and professionals during the tendering, bid evaluation and contract implementation stages of construction contract. For instance, in 2009, the Serious Fraud Office in UK exposed Mabey and Johnson Ltd, a British construction company, for foreign bribery and corruption practices in Ghana. Mabey and Johnson were accused of inducing politicians and government officials in Ghana with bribes totalling $£ 470,000$, to win bridge contracts between 1994 and 1999. The company was found guilty of bribery and fined $£ 6.6$ million, while three executives of the company were given prison sentences [47].
In an effort at stemming the tides of procurement corruption in Ghana, the Public Procurement Act 2003 (Act 663) was passed to guarantee efficiency, transparency, and accountability in public procurement. Nevertheless, the Act makes provision for procurement entities to engage in single-source procurement (in exceptional circumstances) upon the approval from the Public Procurement Authority (PPA). This provision and its process are widely perceived to have been abused. Adofo [48] opined that it is a medium for politician and their cronies to enrich themselves by inflating the cost of the goods and services to be procured. This non-competitive procurement of contracts has tendency of low level of transparency, less democratic oversite, inadequate value for money audit and corruption risks [49].

\section{SWOT Matrix}

The research is conducted at the construction industry level in Ghana, where it seeks to explore the factors that influence the performance of the construction industry within the national context. These factors may be internal and, as such, are driven by the characteristics or the operations of the construction industry, while others are being offered and driven by other factors, external to the construction industry, but having significant influence on the performance of the construction industry. In accordance with the SWOT analysis, the internal and external factors are summarised in Figure 1. All the internal factors, i.e., strengths and weaknesses, are those that are within the jurisdiction of the construction industry to control. On the other hand, the external factors, i.e., opportunities and threats, are those that are presented and/or controlled by other forces which are external to the construction industry. Thereafter, correlation is made between the internal factors, strengths and weaknesses of the industry, and the external factors, opportunities and threats as shown in Table 3. This has been done on the principles of "taking advantage of the strengths, minimising weaknesses, exploiting opportunities and neutralising threats" $[10,50]$ through development of strategies.

The following four strategies are used in the SWOT Matrix:

- The $\mathrm{S} / \mathrm{O}$ strategy to take advantage of strengths in favour of opportunities identified.

- The W/O strategy to overcome weaknesses by taking advantage of the opportunities. They may however require additional resources in order to take advantage of the opportunities.

- The S/T strategy to enable the industry to confront the threats with the industry's strength

- The W/T strategy to eliminate (overcome) weaknesses and avoiding threat. 


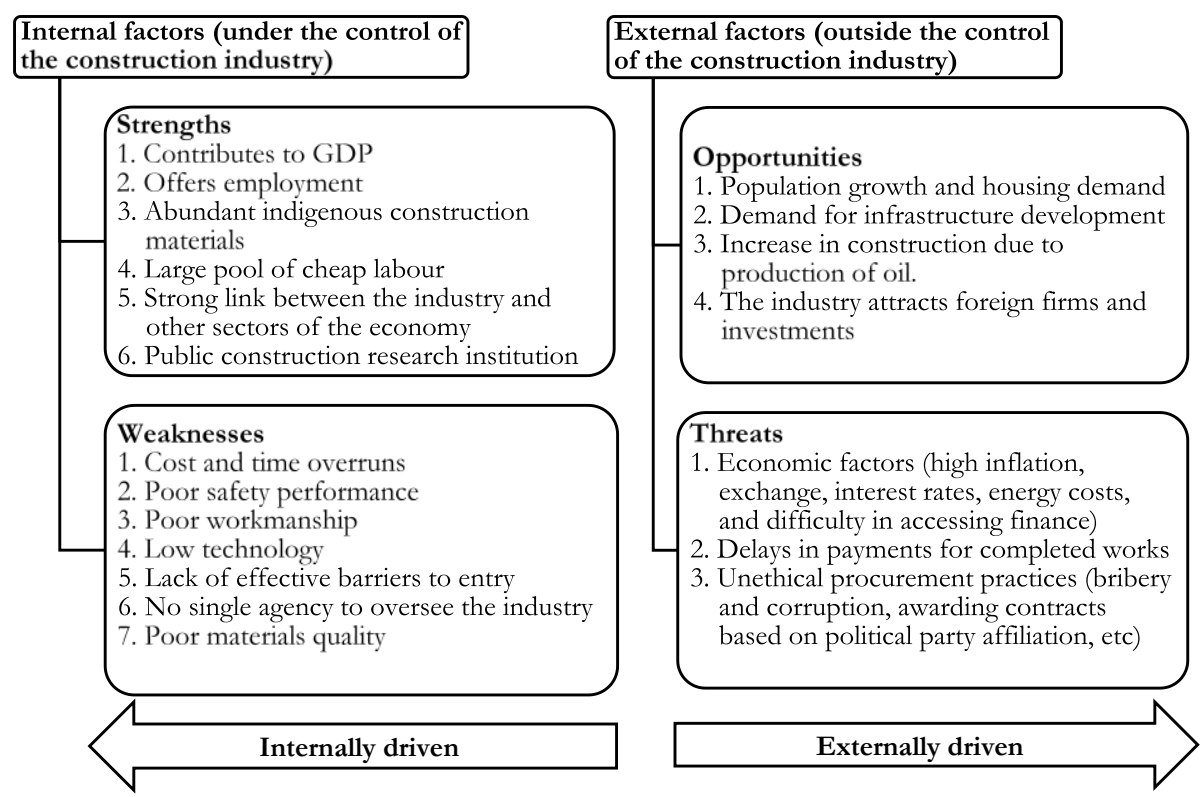

Figure 1. SWOT of the Construction Industry in Ghana.

Table 3. SWOT Matrix for the Construction Industry in Ghana

\begin{tabular}{|c|c|c|c|}
\hline & & Strengths (S) & Weakness (W) \\
\hline & Internal factors & 1. Contributes to GDP & 1. Cost and time overruns \\
\hline & & 2. Offers employment & 2. Poor safety performance \\
\hline & & 3. Abundant indigenous construction & 3. Poor workmanship \\
\hline & & materials & 4. Low technology \\
\hline & & 4. Large pool of cheap labour & 5. Lack of effective barriers to entry \\
\hline & & $\begin{array}{l}\text { 5. Strong link between the industry and } \\
\text { other sectors of the economy }\end{array}$ & $\begin{array}{l}\text { 6. No single agency to oversee the } \\
\text { industry }\end{array}$ \\
\hline External factors & & $\begin{array}{l}\text { 6. Public construction research } \\
\text { institution }\end{array}$ & 7. Poor materials quality \\
\hline Opportunities $(\mathrm{O})$ & & S/O Strategies & W/O Strategies \\
\hline
\end{tabular}

1. Population growth and housing 1. Continuity of work from government. 1. Training and development of skills demand

$$
\text { (S1,2,5/O1,2,3) }
$$

2. Demand for infrastructure development

3. Increase in construction due to production of oil.

4. The industry attracts foreign firms and investments
2. Increase investment in technology research and development (S6/O4)

3. Encourage local contractors to build up partnerships and develop innovative construction methods and experience to improve their competitiveness. (S2/O4)

$$
\text { (W2,3/O4) }
$$

2. Invest in IT and technology in construction (W3,4/O4)

3. Create a statutory body responsible for the industry (W6/O1,2,3,4)

4. Emphasise that contractors seeking public projects must demonstrate ability to deliver good project outcomes (cost, time, quality and safety). (W1,2,3,4,5/O4)

5. Raise barriers to entry for contractors. (W5/O4)

\begin{tabular}{lll}
\hline Threats (T) & S/T Strategies & W/T Strategies
\end{tabular}

1. Economic factors (inflation, 1. Develop and use of locally produced 1. Secure funding before projects start. exchange, interest rates, energy costs, access to finance) construction materials and avoid gross importation. (S3/T1)

2. Payment delays for works done 2. Establish exhaustive policy and

3. Unethical procurement practices standard systems (S5/T2,3)

(bribery and corruption, awarding contracts based on party affiliation, etc)

3. Government should step up efforts to arrest the high inflation, interest and exchange rates. (S3,5/T1)

4. Deal legally with perpetrators of unethical procurement practices. (S5/T3)
(W1/T2)

2. Reduce bureaucracy and politics in project payment (W1/T2)

3. Ensure that contracts are (by policy) independent of government changes (W1/T2,3)

4. Ensure that regulations relating to procurement are strictly enforced. (W1,2/T3)

5. Anticipate fluctuations in economic factors into project budgets. (W1/T1,2)

6. Promote safety through the procurement process. (W2/T3) 


\section{Strategies for Improvements}

Through the conduct of the SWOT analysis, a clear picture of the internal and external environments of the construction industry in Ghana has emerged. The matrix has revealed strategies that could be used to take advantage of the strengths, minimise weaknesses, exploit opportunities, and neutralise threats $[10,50]$. Below discuss the strategic recommendations proposed to improve the performance of the construction industry in Ghana.

\section{S/O Strategy: Investment to Facilitate Innovation and Growth}

In order to take advantage of the strength and exploit the opportunities of the construction industry, investment should be made to facilitate innovation and growth. Promoting innovation and technology is one of the most influential tools that can be used to stimulate change, improve an industry's competitiveness, generate growth and create jobs [51]. Studies show a solid link between investment in innovation, and profitability and growth of industries. Investment should be made to drive innovation and growth in the construction industry through direct and indirect financing. Direct financing includes private and public financing. Companies that operate in the industry can privately finance innovation. Also, government through public financing schemes such as seed finance, co-investment funds, technology and innovation funds, and innovation prizes can promote innovation and growth in the industry. Also, government should increase investment in R\&D activities of the BRRI and other institutions in the construction sector, considering that the industry is the second highest contributor to GDP in Ghana.

Furthermore, government can indirectly invest into innovation in the construction industry through tax incentives. Many countries provide tax incentives for technology development and innovation, such as tax credits and tax deductions on innovation, and R\&D. For example, in Australia, the R\&D Tax Incentive programme operates to help firms intensify their $R \& D$ activities and innovate [51].

Even though finance plays crucial role in technological change, innovation and development, investment in innovation also require institutions, time, human, and other resources. Therefore, it is advocated that, a statutory body be created to have oversight responsibility over the construction industry in Ghana. The absence of a central body has been partly linked to the industry's weaknesses [52]. For instance, in Malaysia, the Construction Industry Development Board (CIDB) has been established as a statutory body, to among other functions to promote and stimulate the development, improvement and expansion of the industry. It is recommended that a central agency should be established along the mandate of CDB Malaysia to regulate and ensure the continuous development of the construction industry in Ghana.

\section{W/O Strategy: Human Resource Development}

Although the construction industry in Ghana has a large pool of cheap workforce, the industry exhibits a weakness of poor workmanship. This has been attributed partly to lack of skills and experience of its workforce [53]. Considering that the construction industry is one of the most dynamic and complex industrial environments [54] and also heavily relies on the skills and experience of the workforce, there needs to be development of these skills. Human resource in construction can be developed through formal and informal training. The formal training is geared toward professional or academic qualifications from training institutions such as the universities, polytechnics, technical schools/colleges, etc. Also, informal training includes apprenticeship, mentoring, coaching, induction programmes, job shadowing, career development, encouraging good practice, etc. It is recommended that, government through the Council for Technical and Vocational Education and Training (COTVET) should facilitate the training, certification and standardisation of qualifications for construction artisans. Developing the knowledge and skills of workers will impact positively on their quality of work and improve the performance of the industry.

\section{S/T Strategy: Development and Enforcement of Policy and Standard Systems}

Government is encouraged to develop and implement exhaustive policies and standards relating to the construction industry. These policies include those relating to health and safety, and standards of building materials. Studies by Kheni [16] and Frimpong [55] provided evidence of challenges in managing construction health and safety in Ghana as a result of weak regulatory systems, inefficient enforcement and lack of national framework for managing health and safety. To address these challenges, it is recommended that acts/policies must be passed to regulate and enforce health and safety on construction sites.

Similarly, guiding policies and strict enforcement of construction materials standards are advocated. With the launch of the Ghana Building Code in 2018, and together with the use of ISO standards, the industry has regulations and standards relative to construction materials. However, many unscrupulous businesses have taken advantage of weaknesses in the enforcement regimes by supplying sub-standard construction materials into the market. These sub-standard materials affect the quality of construction and put lives at risk. It is recommended that, there must be 
policies to guide construction firms and professionals to ensure that materials they procure and use in construction are 'fit for purpose' and conform with building codes and standards.

\section{W/T Strategy: Conducive Procurement Practice}

Besides the cost of government wage bill, public procurement accounts for the largest share of government expenditure [56]. This make public procurement a lucrative area for corruption and political patronage. However, the Public Procurement Act 2003 (Act 663) provides a very effective tool for the fight against procurement corruption in Ghana. It is recommended that the Public Procurement Authority should be adequately resourced to monitor and supervise public procurement entities and ensures strict compliance with the Act. Continuous monitoring will reduce the probability of occurrence of unethical procurement practices within the construction industry. Again, all entities and practitioners who breach the provisions in the Act must be punished administratively and/or criminally, as provided by the Act. Furthermore, the Act must operate without the perceived manipulations especially in sole sourcing.

Apart from fighting unethical procurement practices, the Act makes provision for timely payments to contractors for works done. The general conditions of public contracts clearly indicate that certificates issued by contractors and certified by project managers should be honoured within 28 days of issuance of the claim [57]. This provision must also be strictly enforced in order to avoid payment delays to contractors.

Finally, the construction industry needs greater political consensus, stronger commitment and consistency in the administration of public projects. Politicking with construction projects increase risks, reduce market confidence and makes it difficult for the industry to be efficient. It is recommended that government and other industry players must jointly plan and communicate to ensure more predictability and certainty of public project outcomes.

\section{Conclusion}

Conducting SWOT analysis has clearly revealed a picture of the internal and external environment of the Ghanaian construction industry. The strength of the industry stems from its abundant indigenous construction materials and availability of plentiful cheap labour. However, the industry is noted for several weaknesses including, poor health and safety performances, cost and time overruns, low technology, poor workmanship, among others. While population growth, urbanisation and economic growth in Ghana presents unique opportunities for the construction industry, many external factors threaten the performance of the industry. These factors include high inflation, exchange rate, payment delays, politics and corruption.

This research proposed using four strategies based on Strength/Opportunities, Weakness/Opportunities, Strength/Threats and Weakness/Threats, and made recommendations to improve the performance of the construction industry in Ghana. These strategic recommendations are training and developing construction skills, creating an industry statutory body, developing and implementing exhaustive policy systems and standards, investing in research and development, strictly adhering to procurement rules, and developing and using local construction materials.

\section{References}

1. Chen, J.J., The Characteristics and Current Status of China's Construction Industry, Construction Management and Economics, 16(6), 1998, pp. 711-719.

2. Ghana Statistical Service, 2017 Annual Gross Domestic Product, Ghana Statistical Service, Accra, 2018.

3. Ghana Statistical Service, 2015 Labour Force Report, Ghana Statistical Service, Accra, 2016.

4. Durdyev, S., Omarov, M., and Ismail, S., SWOT Analysis of the Cambodian Construction Industry within the ASEAN Economic Community, Proceedings of the 28th IBIMA conference on Vision 2020: Innovation Management, Development Sustainability, and Competitive Economic Growth, Seville, Spain, November 9-10, 2016, pp. 23352341.

5. Glaister, K.W. and Falshaw, J.R., Strategic Planning Still Going Strong, Long Range Planning, 32(1), 1999, pp. 107-116.

6. Panagiotou, G., Bringing SWOT into Focus, Business Strategy Review, 24(2), 2003, pp. 8-16.

7. Valentin, E.K., SWOT Analysis from a Resourcebased View, Journal of Marketing Theory and Practice, 9(2), 2001, pp. 54-69.

8. Helms, M.M. and Nixon, J., Exploring SWOT Analysis - Where are We Now?: A Review of Academic Research from the Last Decade, Journal of Strategy and Management, 3(3), 2010, pp. 215251.

9. Zhao, Z.Y. and Shen, L.Y., Are Chinese Contractors Competitive in International Markets?, Construction Management and Economics, 26(3), 2008, pp. 225-236.

10. Lu, W.S., Li. H., Shen, L.Y., and Huang, T., Strengths, Weaknesses, Opportunities, and Threats Analysis of Chinese Construction Companies in the Global Market, Journal of Management in Engineering, 25(4), 2009, pp. 166-176. 
11. Cunningham, W.F., and Cunningham, M.A., Principles of Environmental Science: Inquiry and Application, Ninth edition, McGraw Hill Education, New York, 2020.

12. Mogbo, T.C., The Retail Trade and Building Materials in Nigeria, The Quantity Surveyor, 29, 1999, pp. 42-45

13. Darko, E. and Löwe, A., Ghana's Construction Sector and Youth Employment, Overseas Development Institute, London, 2016.

14. Laryea, S.A., Challenges and Opportunities Facing Contractors in Ghana, Proceedings of West Africa Built Environment Research (WABER) Conference, Accra, Ghana, July 27-28, 2010, pp. 215-226.

15. Akomah, B.B., Nimo-Boakye, A., and Fugar, F.D.K., Safety on Ghanaian Construction Sites: The Role of the Employer and the Employee, Proceedings of West Africa Built Environment Research (WABER) Conference, Accra, Ghana, July 27-28, 2010, pp. 477-487.

16. Kheni N.A., Impact of Health and Safety Management on Safety Performance of Small and Medium-sized Construction Businesses in Ghana, $\mathrm{PhD}$ Thesis, Loughborough University, Loughborough, 2008.

17. Kpamma, Z. and Adjei-Kumi, T., The Lean Project Delivery System (LPDS): Application at the Design and Documentation Stage for Construction Projects in Ghana. Proceedings of West Africa Built Environment Research (WABER) Conference, Accra, Ghana, July 27-28, 2010, pp. 597 604.

18. Ofori, G., Transparency in Construction. In: Ofori, G., Editor, Contemporary Issues in Construction in Developing Countries, SPON Press, Abingdon, 2012.

19. Ofori-Kuragu, J.K., Baiden B., and Badu, E., Factors Affecting Ghanaian Contractor Performance, Proceedings of the CIB W107 2014 International Conference, Lagos, Nigeria, January 2830, 2014, pp. 275-285.

20. Williams, M.J., Bricks-and-mortar Institutions Matter, Project Delivery and Unfinished Infrastructure in Ghana's Local Governments, International Growth Centre, London, 2015.

21. Ghana Statistical Service, 2010 Population and Housing Census, Ghana Statistical Service, Accra, 2014.

22. Ghana Investment Promotion Centre (GIPC), Ghana Investment Profile: Property Development, Ghana Investment Promotion Centre, Accra, 2006.

23. Institute of Statistical, Social and Economic Research, Ghana Social Development Outlook 2012, Institute of Statistical, Social and Economic Research, Accra, 2013.
24. Foster, V. and Pushak, N., Ghana's Infrastructure: A Continental Perspective, Policy Research Working Paper 5600. The World Bank, Washington, DC, 2011.

25. Armah-Attoh, D., Ghana's Oil Revenue Management: Convergence of Popular Opinion, the Law and Practice, Afrobarometer Policy Paper No. 19, 2015.

26. Wooldridge, A., A Special Report on Innovation in Emerging Markets, The Economist, 395(8678), April 17-23, 2010.

27. Ofori, G., Pin, T., Leong, C. and Lean, C.S., Do Foreign Contractors Help Host-country Construction Industries to Develop? Case of Singapore, Proceedings of CIB-TG29, Contractor Development, Kampala, Uganda, 1999, pp. 90-99.

28. Ayirebi-Dansoh, K., Strategic Planning Practice of Construction Firms in Ghana, Construction Management and Economics, 23(2), 2005, pp. 148-163.

29. Ghana Statistical Service, Consumer Price Index (CPI) 2017, Ghana Statistical Service, Accra, 2017.

30. Oladipo, F.O. and Oni, O.J., A Review of Selected Macroeconomic Factors Impacting Building Material Prices in Developing Countries - A Case of Nigeria, Ethiopian Journal of Environmental Studies and Management, 5(2), 2012, pp. 131-137.

31. Kaming, P.F., Olomolaiye, P.O., Holt, G.D., and Harris, F.C., Factors Influencing Construction Time and Cost Overruns on High-rise Projects in Indonesia, Construction Management and Economics, 15(1), 1997, pp. 83-94.

32. Danso, H. and Antwi, J.K., Evaluation of the Factors Influencing Time and Cost Overruns in Telecom Tower Construction in Ghana, Civil and Environmental Research, 2(6), 2012, pp. 15-24.

33. Bank of Ghana, Inflation Rate in Ghana, Bank of Ghana, Accra, 2018.

34. Ofori P.A., Twumasi-Ampofo, K., Danquah, J.A., Osei-Tutu, E., and Osei-Tutu, S., Investigating Challenges in Financing Contractors for Public Sector Projects in Ghana, Journal of Building Construction and Planning Research, 5(2), 2017, pp. 58-70.

35. Eiteman, D.K., Stonehill, A.I., and Moffett, M.H., Multinational Business Finance, Tenth edition, Addison-Wesley, Newark, 2014.

36. Ghana Oil Marketing Company (GOIL), GOIL reduces fuel prices to below Ghф5 per litre, 2018, accessed on 6 December 2018, from http://goil. com.gh/goil-reduces-fuel-prices-to-below-ghc-5cedis-per-litre/.

37. Agyakwa-Baah, A., A Study into Risk Assessment and Management Practices within Ghanaian Medium and Large Construction Organisations, MSc Thesis, Sheffield Hallam University, Sheffield, 2009. 
38. Adams, F.K., Risk Perception and Bayesian Analysis of International Construction Contract Risks: The Case of Payment Delays in Developing Economy, International Journal of Project Management, 26(2), 2008, pp. 138-148.

39. Ammah N.A and Adogla-Bessa D., Aggrieved GETFund Contractors to Stage Demo on August 1. Citi Newsroom, 2018, accessed on 13 November 2018, from https:/citinewsroom.com/2018/07/23/ aggrieved-getfund contractors-to-stage-demo-onaugust-1/.

40. Goodman, L.J. and Love R.S., Project Planning and Management: An Integrated Approach, Pergamon Press, New York, 1980.

41. De la Cruz, M.P., Del Cano, A., and De la Cruz, E., Downside Risks in Construction Projects Developed by the Civil Service: The Case of Spain, Journal of Construction Engineering and Management, 132(8), 2006, pp. 844-852.

42. Damoah I.S., Mouzughi Y., and Kumi D.K., The Effects of Government Construction Projects Abandonment: Stakeholders' Perspective, International Journal of Construction Management, In Press, 2018, https://doi.org/10.1080/15623599. 2018.1486172.

43. Chileshie, N. and Yirenkyi-Fianko, A.B., An Evaluation of Risk Factors Impacting Construction Projects in Ghana, Journal of Engineering, Design and Technology, 10(3), 2011, pp. 306-329.

44. Williams, M.J., The Political Economy of Unfinished Development Projects: Corruption, Clientelism, or Collective Choice?, American Political Science Review, 111(4), 2017, pp. 705-723.

45. Osei-Tutu, E., Kissi E., and Osei-Tutu S., Sole Sourcing Procurement: The Ghanaian Procurement Experience, Building and Road Research Institute, Kumasi Council for Scientific and Industrial Research, Accra, Ghana, 2010.

46. Ameyaw, E.E., Pärn E., Chan A.P.C., OwusuManu D., Edwards D.J. and Darko A., Corrupt Practices in the Construction Industry: Survey of Ghanaian Experience, Journal of Management in Engineering, 33(6), 2017.

47. Sarpong, D., Sajdakova, J., and Adams, K., The Mabey and Johnson Bribery Scandal: A Case of
Executive Hubris, Thunderbird International Business Review, 61(2), 2018, pp. 387-396.

48. Adofo, R. (2016). Sole Sourcing is a Clever Way by Which Ghanaian Politicians \& CEOs Swindle the Country, 2016, Accessed on 7 November 2018, from http://www.ghanaweb.com/GhanaHome Page/NewsArchive/Sole-sourcing-is-aclever- wayby-which-Ghanaian-politicians-CEOs-swindlethe-country-515022.

49. Organisation for Economic Co-operation and Development, Integrity in Public Procurement: Good Practice from $A$ to $Z$, OECD Publishing, Paris, 2007

50. Jiang R., Mao, C., Hou, L., Wu, C., and Tan, J. (2018), A SWOT Analysis for Promoting Off-site Construction under the Backdrop of China's New Urbanisation, Journal of Cleaner Production, 173, 2018, pp. 225-234.

51. United Nations Trade and Development Broad, Investing in Innovation for Development, United Nations, Geneva, 2013.

52. Ofori-Kuragu, J. K., Owusu-Manu, D., and Ayarkwa, J., The Case for the Construction Industry Council, Ghana, Journal of Construction in Developing Countries, 21(2), 2016, pp. 131-149.

53. Love, P.E.D., Wyatt, A.D., and Mohamed, S., Understanding Rework in Construction, Proceedings of International Conference on Construction Process Re-engineering, Gold Coast, Australia, July 14-15, 1997, pp. 269-278.

54. Loosemore, M., Dainty, A.R.J., and Lingard, H., Human Resource Management in Construction Projects: Strategic and Operational Approaches, Spon Press, London, 2003.

55. Frimpong, B.E. Can the Management of Health and Safety within the Ghanaian Contractor's Organisation be Improved by Using the UK Model?, Master Thesis, HAN University of Applied Science, Arnhem, 2009.

56. Public Procurement Authority, Electronic Bulletin, July-August 2013, 4(4), Public Procurement Authority, Accra, 2013.

57. Public Procurement Authority, Public Procurement Act, 2003, Act 663 (Ghana), Public Procurement Authority, Accra, 2003. 